\title{
SACRIFÍcio E INDIVIDUALIDADE: LASK LEITOR DE FiCHTE
}

\author{
Federico Ferraguto 1
}

Resumo: O artigo trata da relaçáo entre individualidade e valor, na filosofia transcendental, a partir de uma análise da interpretação da filosofia de J. G. Fichte dada por Emil Lask, no livro publicado em 1903, Fichtes Idealismus und die Geschichte. O artigo visa a mostrar como a radicalização do transcendentalismo o orienta a um realismo náo empírico, o qual impede ao transcendentalismo de realizar-se exclusivamente na forma da investigação autorreflexiva das estruturas da consciência e o traduz em uma valorização da práxis. Depois de uma descrição geral das perspectivas abertas pela filosofia laskiana e das razóes para valorizar o Fichte-Buch de Lask $(\$ 2)$, seráo esclarecidos os conteúdos e o contexto de amadurecimento da tese laskiana em relação a três interlocutores específicos: Windelband, Rickert e Liebmann ( $\$ \$ 3-4)$. Por fim, serâo avaliadas a solidez e a fecundidade de duas questóes decisivas para o desenvolvimento do pensamento fichtiano: a relação entre filosofia e vida $(\$ 5)$ e aquela entre individualidade e sacrifício (\$ 6).

Palavras-ChaVE: Fichte. Lask. Neokantismo. Filosofia transcendental. Individualidade.

\section{Depois de Kant, entre idealismo e realismo}

No curso do último decênio do século XVIII, os resultados da filosofia de Kant definem o horizonte geral do debate filosófico alemão. De fato, a filosofia de Kant não é concebida como uma das tantas filosofias possíveis, e sim como um ponto de não retorno da reflexão filosófica. ${ }^{2} \mathrm{O}$ criticismo kantiano

\footnotetext{
${ }_{1}^{1}$ Professor da Pontifícia Universidade Católica do Paraná (PUCPR), Curitiba, PR - Brasil. (D) https:// orcid.org/0000-0002-3874-8300 E-mail: federicoferraguto@yahoo.it

2 Uma justificativa clara e sintética dessa tese geral encontra-se em Henrich (2005, p. 23). Henrich resume os resultados de uma pesquisa, teórica e histórico-filosófica, apresentada de uma maneira detalhada em Henrich (1991) e Henrich (2004). A ideia de a filosofia kantiana representar o horizonte problemático geral do debate filosófico alemão é desenvolvida já em Verra (1956), que interpreta o desenvolvimento do pensamento de autores supostamente antikantianos (Jacobi, Hamann, Herder) em relação à discussão que tem em torno da filosofia crítica. Indicaçôes interessantes acerca da percepção dos protagonistas do debate filosófico alemáo podem ser encontradas em Niethammer (1795, p. 11-12) e em Reinhold (1801-1803, I, p. III). Não faz parte dos objetivos deste artigo apresentar detalhadamente a posição de cada protagonista da filosofia pós-kantiana. Para mais informações a
}

http://dx.doi.org/10.1590/0101-3173.2019.v42n4.07.p125

This is an open-access article distributed under the terms of the Creative Commons Attribution License. 
permite mover o eixo dos conteúdos do conhecimento - variáveis, mutáveis e contingentes - às suas formas, constantes e universais. Com a filosofia crítica, a razão humana pode ancorar-se em princípios sólidos e definitivos. E, sob essa base, pode desenvolver com sucesso a sua obra esclarecedora em todos os campos da vida do ser humano. ${ }^{3}$ Nesse nível, fazer filosofia significa decompor as estruturas que caracterizam a razão finita e evidenciar um núcleo especulativo que dá sentido tanto ao saber filosófico como à vida, da qual a filosofia deve necessariamente diferenciar-se. Trata-se do chamado "idealismo", a ser entendido no sentido fichtiano, apresentado na Primeira introdução na doutrina da ciência de 1797, de uma posição filosófica focada nas estruturas da subjetividade e independente da admissáo de um objeto externo como fundamento de todo saber (GA, I, 4, p. 190).

Essa descrição geral dos desenvolvimentos produzidos pelo kantismo, do qual são protagonistas o primeiro Reinhold e Fichte, deve acompanhar uma série de apontamentos críticos que evidenciam os seus elementos mais frágeis e orientam a discussão filosófica pós-kantiana em direção a uma filosofia especulativa (VERRA, 1956). Segundo autores como Schulze ou Maimon, embora a filosofia crítica seja expressão de uma certa coerência argumentativa, Kant não fora capaz de determinar de que modo é possível aplicar as formas do intelecto, não originadas na empiria, a dados empíricos concretos e individuais. Em uma palavra: Kant não teria esclarecido como conciliar as formas da razão com aquilo que estruturalmente a excede e que, portanto, pode ser considerado irracional ou extrarracional. ${ }^{4}$ Tal crítica, feita de um ponto de vista

respeito, ver Frank (1997), Beiser (2002), Ameriks (2000), Pinkard (2002 em especial p. 82-87 e 105 132, acerca da apropriação da filosofia kantiana pelos supostos antikantianos e românticos), Zöller (2000a).

${ }^{3}$ Trata-se da interpretação dada por Reinhold, nas Cartas sobre a filosofia kantiana, publicadas em 1786 no Teutscher Merkur e, de uma maneira mais sistemática, na Fundamentschrift de 1791. Ver, a respeito, Reinhold (2011, p. 5-13) e os ensaios publicados por Di Giovanni (2010), que discutem a retomada reinholdiana do conceito kantiano de esclarecimento.

${ }^{4}$ Trata-se inicialmente da interpretação da filosofia kantiana dada por Maimon, no Ensaio sobre filosofia transcendental (Versuch über die Transzedentalphilosophie), de 1790. Ver Maimon (1965, II, p. 62-65, 187-188, 370-373). As questôes que caracterizam a interpretação de Maimon são basicamente duas: a) a possibilidade de conceituar a coerência entre formas a priori do entendimento e dado a posteriori e b) em qual sentido algo puramente dado pode ser conceituado por meio da inteligência, sendo que dado e inteligência são heterogêneos (MAIMON, 1965, IV, p. 35). Maimon acredita que o ganho metodológico kantiano seja o de investigar o problema das condiçốes a priori da compreensão dos objetos reais. Maimon alega, porém, que o dualismo kantiano expresso na distinçâo radical entre sensibilidade e entendimento tornaria o problema irresolúvel, pois entendimento e sensibilidade são duas faculdades distintas e garantiriam apenas uma modalidade de conhecimento, mas não poderiam ser sintetizadas (MAIMON, 1965, II, p. 63). Para Maimon, essa argumentaçáo traria à luz 
epistemológico, deve ser seguida também por uma discussão, por assim dizer, metafísica ${ }^{5}$, relativa à possibilidade de rastrear na racionalidade finita, cuja expressão mais clara é a lógica formal, um núcleo que a transcende e a constitui. Esta é a tendência "realista" que se abre nos limiares do século XVIII, e interessa ao Reinhold do realismo racional, a Bardili, ao chamado Fichte tardio, a Schelling, a Hegel e a outros autores menores. ${ }^{6}$ Sem querer exagerar,

a fraqueza da dedução transcendental kantiana. Kant, de fato, teria respondido à questão quid juris, sustentando que a aplicação das formas a priori do entendimento à sensibilidade é uma condição necessária para a possibilidade da experiência. Contudo, ele simplesmente daria uma resposta afirmativa (e não legitimada) à questão quid facti, quer dizer, à questão relativa ao fato específico da experiência (MAIMON, 1965, p. IV, 465). Então, para Maimon, ou a filosofia transcendental seria uma investigação a priori, que dá conta da estrutura formal do conhecimento sem dar conta do próprio fato da experiência, ou ela focaria no fato da experiência, mas a sua compreensão continuará sendo irracional. Essa interpretação foi aprofundada e valorizada por W. Windelband, na sua História da filosofia (WINDELBAND, 2010, p. 616), e, graças ao filtro de Windelband, chega a despertar a atençâo de Emil Lask. Uma interpretação da filosofia transcendental enquanto uma posiçấo que não consegue dar conta da relação entre aquilo que pode ser chamado de racional e o que excede a razão caracteriza o ceticismo de G. E. Schulze e, em especial do apresentado na obra Aenesidemus (1792). Essa interpretação fica evidente em Schulze (1912, p. 202-206, 295-296).

5 O termo "metafisica" é tomado no sentido kantiano - domínio que ultrapassa o campo da experiência possível (A, VIII) - e no fichtiano de investigação que indica as condiçôes não-empíricas de possibilidade de toda experiência (GA, IV, 2, p. 19). Sobre a relação de continuidade entre a concepçáo kantiana e a fichtiana, ver Zöller (2000a).

6 Poder-se-ia chamar essa tendência da filosofia de "realista", no sentido que atribuíram a essa palavra Reinhold e Bardili. Em especial, a influência de Bardili e da sua obra Contorno de logica primeira (BARDILI, 1800) sobre a discussão filosófica do começo do século XIX parece ser decisiva, e não apenas sobre o pensamento de Reinhold, mas sobre o de Fichte e do jovem Hegel e de Schelling também (ZAHN, 1965). Em princípio, essa influência seria devida à tese, conforme a lógica kantiana baseada sobre a síntese a priori tornaria evidente o "sacrifício de toda filosofia à sensibilidade", destacado de maneira exemplar pelo próprio Fichte. Com a sua concepção da lógica, Kant explicaria uma ligação "exclusivamente privativa" entre razão e mundo, uma vez que "a natureza não teria nem uma lógica, nem uma lógica peculiar: o mundo não seria um sistema [...] o acaso e o arbítrio seriam as suas leis supremas" (BARDILI, 1800, p. 12). Apenas o eu poderia retificar essa falta de sentido, mas ele continuaria a escolher arbitrariamente os seus escopos e os instrumentos da sua ação. A tarefa do realismo racional bardiliano seria, pelo contrário, o desenvolvimento de uma concepção da lógica como uma análise do pensamento puro e absoluto (BARDILI, 1800, p. 3-4), pelo qual se tem que derivar um objeto real nas suas variadas articulaçóes. O realismo bardiliano é desdobrado ao longo do desenvolvimento do Contorno e aprofundado sobretudo graças ao trabalho de Reinhold, nos Beyträge zur leichtern Ubersicht des Zustandes der Philosophie beym Anfänge des XIX Jahrhunderts de 1801-1803. Nessa obra, Reinhold elabora uma versão do realismo racional mais clara que a bardiliana e busca levar à tona a sua importância histórica, isto é, a sua função esclarecedora acerca das discussóes filosóficas daquela época. Em geral, para Reinhold, o realismo bardiliano teria que ser privilegiado, pois ele seria mais coerente com a tarefa específica da própria busca filosófica. A filosofia, de fato, consistiria na fundamentação da realidade do conhecimento (REINHOLD, 1801-1803, I, p. 1) por meio da derivaçáo do cognoscível e do próprio conhecimento de um fundamento absoluto, de um prius ou de um "vero originário" (REINHOLD, 1801-1803, I, p. 71). O vero originário é algo objetivo e não deveria ser trocado pelo que seria alcançável pelo conhecimento individual. Este 
e sustentar com Gadamer que o "neokantismo foi muito mais um retorno a Fichte" (GADAMER, 1995, p. 88) que ao próprio Kant", vale a pena ressaltar que, mesmo na discussão sobre Kant desenvolvida na assim chamada Badische Schule, nos inícios de 1900, se retoma o tema do relacionamento entre razão e irracional (BEISER, 2008a), assumindo igualmente os instrumentos conceituais e argumentativos disponibilizados pela Wissenschafstlehre de Fichte (de agora em diante $W L$ ).

O objetivo desta discussão é valorizar a fundação kantiana e desenvolvêla, sem chegar à sólida especulação hegeliana, mas também sem naufragar no ceticismo de Maimon. ${ }^{8}$ Entre as manifestaçóes mais vigorosas desse uso de Fichte, pode-se contar a tese que Emil Lask publica, em 1903: Fichtes Idealismus und die Geschichte. Esse livro, juntamente com Fichte et son temps, de Xavier Leon, surgido, contudo, duas décadas depois, pode ser considerado "o início da pesquisa moderna sobre Fichte" . $\mathrm{O}$ livro de Lask apresenta, com certeza,

último seria apenas uma Einbildung, ou uma manifestação (Manifestation, Erscheinung) desse vero. Reinhold considera Kant, Fichte e Schelling como as expressões mais evidentes dessa troca. Fichte, em especial, cometeria três erros fundamentais: a) identificaria conhecimento e experiência; b) trocaria a realidade do conhecimento pelo sentimento da necessidade c) colocaria a questão da subjetividade das representaçôes em função da limitação da espontaneidade subjetiva (REINHOLD, 1801-1803, I, p. 82). Extremamente interessante para compreender a amplitude dessa constelação filosófica, definida pela relação entre idealismo e realismo e pela reflexão sobre a lógica formal como instrumento para explicar e articular essa relação, é a resenha Übersicht der philosophischen Literatur, publicada por REINHOLD, 1801-1803, VI, p. 140-222.

7 Para um estudo sobre a recepção desse problema no quadro das interpretaçôes estritamente kantianas, sobretudo na escola de Marburg e sobre sua atualidade, cf. Devalque (2010).

8 Para entender melhor essa tentativa, seria interessante remontar, mais uma vez, à apresentação da filosofia clássica alemã dada por Windelband, a qual ressalta uma dinâmica que vai da interpretação maimoniana da razão como uma faculdade que não consegue dar conta da concretude da realidade (WINDELBAND, 1910, p. 578) até a posição filosófica hegeliana que, conforme Windelband, compreende a razão como um sistema em que "todo particular encontra a sua realidade e verdade enquanto momento de um todo" (WINDELBAND, 1910, p. 614). Apesar de essa interpretação do desenvolvimento da filosofia clássica alemá ser discutível, tal esquema, como veremos ao longo deste artigo, é o que mais influencia a recepção da filosofia de Fichte por Emil Lask.

9 Beiser (2008b, p. 288). Ao fazer menção e dedicando-lhe uma série de rápidas e gerais observaçóes, Beiser não realiza uma leitura sistemática do Fichte-Buch, nem chega a avaliar o impacto dessa obra sobre os desenvolvimentos internos do pensamento de Lask ou sobre a recepçáo de Fichte que ocorre nas primeiras duas décadas de 1900. Apesar da escassa atenção que a pesquisa filosófica dedicou a ele, o pensamento de Lask exerceu uma grande influência sobretudo sobre o desenvolvimento da fenomenologia transcendental husserliana, conforme indicado pela pesquisa, filologicamente detalhada, de B. Smith e K. Mulligan (SMITH; MULLIGAN, 1993, em especial, p. 4-7) e de Rockmore (1992), que ressalta a influência do pensamento de Lask sobre Lukàcs. É possível agora sustentar que, enquanto a perspectiva filosófica de Emil Lask foi raramente considerada pela literatura secundária, ela foi levada em grande consideraçăo por muitos dos principais expoentes da filosofia 
um exame crítico do pensamento fichtiano que antecipa os desenvolvimentos do pensamento do seu autor e capta aqueles da WL. Em termos teóricos, a leitura de Lask centraliza-se sob o tema do Hingeben, que literalmente significa "dedicação", "abandono", "entregar-se" ou "sacrifício", a ser entendido no sentido de uma recusa de si mesmo em prol de uma instância ou de uma lei que o transcende. Em Lask, o Hingeben assinala a passagem da reflexão transcendental a uma dimensão de sentido que prescinde da relação sujeitoobjeto: o valer (Gelten), que precede e fundamenta a dimensão cognoscitiva e que, portanto, é "irracional” (FI, p. 165). Em Fichte, o Hingeben é um gesto graças ao qual o ser humano concreto se apropria, por meio de uma visão reflexiva, de uma origem que excede o âmbito do conhecimento, inscrevendo a consciência em um horizonte ético-prático (GA, II, 11, p. 89).

Seja em Fichte, seja em Lask, o gesto irracional que motiva a definição do espaço conceitual próprio da visão filosófica acaba evidenciando a dimensão extrarracional de uma lei ou de um valor (Wert) que doa sentido à atividade reflexiva do indivíduo, mas não a produz, nem deriva dela ( FI, p. 106-107). A tarefa da compreensão transcendental seria, portanto, a de evidenciar os limites do próprio saber reflexivo, só para levar à tona o fundamento "real" dele. Real, porém, não significa empírico ou sensível, algo dado e não produzido pelas próprias capacidades intelectuais do sujeito. ${ }^{10}$ Em Fichte, essa dimensão de realidade é definida pelo conceito de absoluto, que só pode ser compreendido como lei, ou exigência universal e extrassubjetiva de justificação infinita que determina o desenvolvimento do saber (FICHTE, 1846, VII, p. 429-430). Para Lask, essa dimensão não empírica é definida pela ideia de objeto, ou de material não empírico que sobra e doa sentido a toda elaboração lógica (LASK, 1923, II, p. 177). ${ }^{11}$ Em ambos os casos, a perspectiva transcendental, quer dizer, a investigação das condiçôes de possibilidade do saber

contemporânea, e que a valorização de seu pensamento poderia permitir reabilitar, além do esquema von Kant bis Hegel, aqueles que, conforme Luigi Pareyson (PAREYSON, 1976), foram compreendidos como os becos sem saída da história da filosofia.

${ }^{10}$ Uma interpretação do desenvolvimento da filosofia clássica alemã como "luta" para alcançar o fundamento real envolvido em todo compreender que parte de uma análise das condiçóes de possibilidade da relação entre sujeito e mundo encontra-se em Beiser (2002, p. 2-3) e em Gabriel (2011). A importância de uma compreensão do desenvolvimento do chamado de "idealismo alemão", no sentido de um realismo não empírico, foi destacada também por Zöller (2000b). Estudos sobre a gênese histórica dessa forma de realismo não empírico no debate entre Fichte, Jacobi, Bardili e Reinhold, o qual ocorre entre 1798 e 1801, foram efetuados por Ferraguto (2015a) e Ferraguto (2015b).

${ }^{11}$ Para esclarecimentos e para uma justificação detalhada desse ponto, cf. Spinelli (2010, p. 158 ss). 
através de uma compreensão das estruturas da subjetividade é radicalizada em uma forma de realismo não empírico, o qual impede ao transcendentalismo realizar-se exclusivamente em uma investigação autorreflexiva das estruturas e das formas da consciência. ${ }^{12}$

Essa impossibilidade traduz a atividade autorreflexiva do transcendentalismo em uma dimensão alternativa. A dimensão suprassensível, que fica para além dos limites do saber, não pode ser trazida à luz apenas por meio da reflexão filosófica, porém, se manifesta em uma práxis, isto é, na atividade concreta de refletir e de desenvolver uma compreensão racional da realidade, que define a filosofia. ${ }^{13}$ Em outras palavras, a dimensão suprassensível implícita no desenvolvimento autorreflexivo da filosofia transcendental não é nem um produto, nem um objeto, e sim o "significado" do próprio refletir filosófico (GODDARD, 2008; FICHTE, 1846, VII, p. 378).

Neste artigo, buscarei ilustrar essa tese teórica mediante uma reconstrução da interpretação de Fichte apresentada por Lask. Depois de uma descrição geral das perspectivas abertas pela filosofia laskiana e das razóes para valorizar o Fichte-Buch de Lask $(\$ 2)$, explicarei os conteúdos e o contexto de amadurecimento da tese laskiana em relação a três interlocutores específicos: Windelband, Rickert e Liebmann (\$ 3-4). Por fim, analisarei a solidez e a fecundidade de duas questóes decisivas para o desenvolvimento do pensamento fichtiano: a relação entre filosofia e vida $(\$ 5)$ e aquela entre individualidade e sacrifício $(\$ 6)$.

\section{Fichte E LASK, UM BiNÔMIO PARA VALORIZAR}

Enzo Paci resume os êxitos do pensamento de Lask escrevendo que "mesmo na alvorecente filosofia de Lask se afirmam os motivos fundamentais do pensamento contemporâneo: o pensamento do pensamento que, com a

\footnotetext{
${ }^{12}$ Ver, a respeito, Rametta (2002).

${ }^{13}$ Essa ideia é discutida e apresentada de maneira detalhada por Gabriel (2011, p. XVIII, 44), que vê em Fichte uma concepção "ampla" da racionalidade, ou seja, não vinculada a uma identificação entre razão e prestaçóes subjetivas, no mesmo sentido do teorizado recentemente por McDowell (1996, p. 62). Para McDowell e Gabriel, uma epistemologia não naturalista, nem coerentista, de fato, não tem que partir mais da distinção entre mente e mundo, e sim da compreensão da razão como "autorreferenciabilidade" pré-subjetiva e real, a qual constitui o pano de fundo das distinçôes que caracterizam todo o saber concreto. Nesse contexto, conforme Gabriel, a performance subjetiva que produz o saber transcendental poderia ser interpretada em termos extrassubjetivos, como instrumento para se realizar a autorreferência da razão (GABRIEL, 2011, p. XII).
} 
sua falência e com o seu perder-se no infinito, anuncia a existência, e, ao mesmo tempo, a irredutibilidade dos valores" (PACI, 1940, p. 60). "Alvorecente" parece ser o adjetivo mais adequado para sintetizar o percurso filosófico e existencial de Lask. ${ }^{14}$ Se é possível sustentar que Lask seja para os especialistas "um mero nome", é porque o seu percurso filosófico se interrompe bruscamente. $\mathrm{O}$ pensador, repetidamente acusado de viver nos abstratos cumes de uma especulação fria e distanciada do real, morre no front russo, com apenas quarenta anos. ${ }^{15}$

No juízo crítico para com os escopos, digamos, puramente existenciais da proposta filosófica laskiana, podem ter incidido dois fatores. O primeiro consiste em uma substancial desvalorização da contribuição do pensamento de Fichte, mesmo nos desenvolvimentos mais maduros do sistema laskiano. Para além da dissertação sobre Fichte, Lask publica ainda outras duas obras importantes, a Logik der Philosophie und die Kategorienlehre, de 1911, e a Lehre vom Urteil, de 1912. ${ }^{16}$ À luz da visão filosófica apresentada nesses dois difíceis livros, a dissertação sobre Fichte é geralmente considerada uma espécie de exercício preliminar que prepara a confrontaçáo com Kant e Hegel e que caracteriza os trabalhos vindouros, mas que não seria marcada por um efetivo interesse pela WL. ${ }^{17}$ Lask seria inicialmente conduzido a Fichte por Windelband e Rickert, contudo, ele se distanciaria em proporção ao destaque de seus mestres. Não se pode, no entanto, conduzir a aparente tomada de distância de Fichte à dessubjetivação do saber, a qual Lask almeja nas suas últimas

\footnotetext{
${ }^{14}$ A vida e a formação de Lask podem efetivamente ser resumidas em pouquíssimos traços. Ele nasce em Wadowice (Polônia), em 1875, de pais judeus. Em 1894, transfere-se para Friburgo. Inicialmente, com intenção de estudar direito, começa a seguir Rickert, com o qual estuda Kant e Fichte, teoria do conhecimento e filosofia dos valores. Com Rickert, Lask desenvolve o seu extraordinário talento para a filosofia sistemática e se doutora, em 1901, com a já mencionada tese sobre Fichte. Nos anos sucessivos, ele vai para Heidelberg. Em 1905, habilita-se com Windelband, graças a um escrito sobre filosofia do Direito. Em Heidelberg, ele recebe a livre-docência, continuando a privilegiar a atividade de pesquisa àquela de ensino. Alista-se como voluntário no exército, com a eclosão da "Grande Guerra" e é enviado aos Cárpatos. Lask morre no front russo, em maio de 1914, e a sua tumba nunca foi encontrada.

${ }^{15}$ Para uma descrição dos traços da personalidade de Lask, cf. Stepun (1929, p. 163 ss).

${ }^{16}$ Uma leitura relativamente aprofundada do Fichte-Buch se encontra em Glatz (2001, p. 230-243). A leitura de Glatz, que tem certamente o mérito de pôr em foco o significado teórico do conceito de Hingeben para o desenvolvimento da filosofia laskiana, não alcança o escopo, no que diz respeito à interpretação da filosofia de Fichte.

${ }^{17}$ Nessa direção parece andar Tuozzolo, 2007, que dedica ao confronto com Fichte poucas páginas, enquanto privilegia a discussão da interpretação laskiana de Hegel, no mesmo sentido da descrição oferecida por Lukács, no seu Nachruf, de 1918 (LUKÁCS, 1918).
} 
duas obras. A dessubjetivação do saber é também um traço peculiar da WL fichtiana ${ }^{18}$, sobretudo nos últimos escritos que Lask, a julgar pelas citaçóes encontradas no seu Fichte-Buch ${ }^{19}$, conhecia bem. Reconsiderar a influência de Fichte sobre a complexidade do pensamento laskiano permitiria estabelecer um vínculo mais claro entre a definição da "lógica da lógica" (argumento das últimas duas obras) e a tematização do problema da história (argumento do Fichte-Buch). Até porque a definição do núcleo irracional, ou extrarracional, da racionalidade, central na tese sobre Fichte, representa o primeiro passo para a reflexão sobre os princípios da lógica de um ponto de vista capaz de compreendê-la na sua complexidade.

Fichte e Lask, de fato, parecem apaixonar-se, com igual ardor, por um único problema: a definição das categorias que ensejam a investigação transcendental, ou aquela relativa aos limites e à potencialidade do saber do saber. Com essa exigência, Lask abre Fichtes Idealismus und die Geschichte. A análise do pensamento fichtiano que há nesse livro teria como escopo oferecer uma contribuição à história do problema da irracionalidade. Ao mesmo tempo, no entanto, o desenvolvimento histórico do problema da irracionalidade, no contexto da filosofia clássica alemã, exerce um papel decisivo na definição lógica (e, portanto, a-histórica) da história mesma. Fichte, segundo Lask, pela primeira vez explicou e tornou possível esse plano de investigação, transpondo o problema da história do âmbito de uma reflexão sobre a história para aquele de uma definição dos seus princípios meta-históricos (FI, p. 19). Eis explicada a relação dos dois conceitos apresentados no título do livro: idealismo e história. Trata-se de estabelecer uma conexão entre a opção filosófica que mais se volta ao problema da irracionalidade, sem renunciar à exigência de efetivar uma investigação filosófico-transcendental em torno dela (idealismo fichtiano) e à dimensão constituída pela própria irracionalidade (história como lugar no qual se realiza uma individualidade irrepetível).

$\mathrm{O}$ segundo fator diz respeito à ideia global da filosofia de Lask. O nexo entre teorético e prático é já uma característica de Fichte $(G A, I V, 2$,

\footnotetext{
${ }^{18}$ Uma interpretação do percurso filosófico de Fichte, nesse sentido, pode se encontrar com clareza em Zöller (2001), Rametta (2013) e Zöller ( 2013).

${ }^{19} \mathrm{O}$ fato de Lask não fazer referência aos escritos teóricos de Fichte dessa última fase reconduz imediatamente àquilo que sustenta Rickert, na conclusão do ensaio de 1899, Fichtes Atheismustreit und die Kantische Philosophie: a última fase do pensamento de Fichte representa um vértice teórico, o qual permanece, todavia, privado de um desenvolvimento claro (RICKERT, 1899, p. 25).
} 
p. 13). ${ }^{20}$ Mas também Lask parece tê-lo presente nos esboços em que pretendia prosseguir o seu sistema. A relação da filosofia com as outras ciências está entrelaçada com seçôes dedicadas à ética e à estética que permitem valorizar aspectos da vida concreta concebida como Erleben e como conduta (Verhalten). Entre essa passagem e a radicalização da lógica em uma "lógica da lógica" existe um nexo fundamental, exibido propriamente no conceito de Hingeben. Na sua reflexão sobre o estatuto da lógica, Lask tenta estender a revolução copernicana de Kant do hemisfério do ser àquele da validade. ${ }^{21}$ A dimensão do valor póe a lógica em relação a um horizonte de sentido que a constitui enquanto tal, antes de todas relaçôes com um dado. A verdade excede a forma do juízo. Pelo contrário, o juízo pode ser considerado verdadeiro só em função da sua maior ou menor conformidade à dimensão do valor. O conhecimento é, então, Hingabe, dedicação ou entrega, do fator lógico-formal àquele "objeto puro" (não-empírico, não-sensível, não ajuizável) que constitui a sua origem..$^{22}$ A relação sujeito-objeto para de ser o motor do conhecimento e a forma pela qual se exprime, ou seja, o juízo torna-se a cifra de uma dimensão não empírica e extrarracional. ${ }^{23} \mathrm{~A}$ raiz da razão consiste, portanto, em um elemento irracional, isto é, não redutível à estrutura proposicional do saber discursivo. No nível do conhecer judicativo, a relação com essa dimensão pode ser apresentada só em termos práticos, como norma, exigência ou dever. ${ }^{24}$

Todavia, a consequência desse discurso no plano ético-prático não se encontra apenas nas últimas anotaçóes de Lask. ${ }^{25}$ É suficiente considerar o plano geral da contraposição que ele institui entre Kant e Fichte, já em 1903. O primado do prático estabelecido na $W L$ de Fichte é a base para uma autêntica

\footnotetext{
${ }^{20}$ Uma interpretaçáo global da doutrina da ciência de Fichte como filosofia baseada na unidade entre teorético e prático encontra-se em Ivaldo (1992).

${ }^{21}$ Indicaçōes a respeito encontram-se em FI, p. 128, 165, 28-44, 73-76 e na Logik der Philosophie (LASK, 1923, II), p. 29 ss.

${ }^{22}$ Esse problema é tratado sobretudo em Die Lehre vom Urteil (LASK, 1923, II, p. 396). Uma interpretação desse modelo teórico em relação à interpretação laskiana de Fichte é dada por Glatz (2001, p. 205).

${ }^{23}$ Sobre isso, cf. Pick (1921).

${ }^{24}$ Ver as anotaçôes conhecidas com o título de System der Philosophie, Lask (1923, III, p. 179). Nas mesmas anotaçóes há uma referência a Fichte. Com efeito, como atesta o recente estudo de Spinelli (2010, p. 198), a posição de Lask nos últimos escritos retoma os resultados do Fichte-Buch e, em especial, a leitura do conceito fichtiano de "eu como ideia" que há em (FI, p. 71-72).

${ }^{25}$ Cf. n. 23.
} 
retomada ou reforma do criticismo que Lask vê ser conduzida em nome da "concretização" e da "realizaçáo". ${ }^{26}$

Concretização: porque Fichte, conforme Lask, diferencia a esfera do valor daquela do ser. Para Fichte, de fato, o valor teria uma estrutura dinâmica, mas não poderia ser alcançado por si mesmo, tornando-se evidente apenas através da sua manifestação em um ente específico. $O$ individual é considerado parte integrante do processo de constituição do valor, não por força de seu "ser", mas em razão de uma visão da sua potencialidade de realizar uma exigência prática. Lask atribui, de fato, à Methodologisierung fichtiana dos conceitos de revelação e de milagre um papel crucial, porque é graças a eles que se pode esclarecer como um fenômeno histórico-individual é capaz de exibir um "novo" não antecipável segundo conceitos. Daqui a noção, central no livro de 1903, de Wertindividualität: individualidade válida ou individualidade de valor. ${ }^{27}$

Realização: porque, para Lask, a conciliação entre hemisfério do valor e realidade empírica não acontece em um terreno extrafilosófico, entretanto, ao longo de um aprofundamento imanente e progressivo dos nexos do saber transcendental. Igualmente na leitura de Lask, as diversas fases do desenvolvimento da WL são sustentadas pela tentativa de pensar a integração da facticidade, ou da irracionalidade, na esfera do saber. Desse modo, segundo Fichte, a filosofia pode dizer-se realizada. ${ }^{28} \mathrm{E}$ só dessa maneira também a tentativa laskiana de ultrapassar o monismo pode ser vista à luz de uma radicalização do transcendentalismo de Kant, ao invés de um retorno à metafísica pré-kantiana (LUKÀCS, 1918, p. 350).

Resulta, assim, difícil pensar que Lask tornou a especulação uma abstrata contemplação de si mesma em constante fuga do mundo (CARRINO,

\footnotetext{
${ }^{26}$ Claudio Cesa, já em um ensaio de 1992 (CESA, 1992, p. 103 e p. 106), define a doutrina da ciência de Fichte como caraterizada pelo "primado do prático", onde "prático" não significa necessariamente "moral". De fato, a distinção entre prático e teorético, que caracterizaria o pensamento fichtiano, retomaria a distinção de Ch. Wolff entre teórico, que reflete o âmbito daquilo que existe, e prático, que reflete o âmbito daquilo que deve ser. $\mathrm{Na}$ medida em que a doutrina da ciência se foca na espontaneidade do eu e, a partir dela, deduz as leis e a estrutura do conhecimento dos objetos, pode-se dizer que ela é definida pelo primado do prático. Indicaçôes nesse sentido encontram-se, entre outros, na Praktische Philosophie de 1794 (GA, II, 3, p. 247), no escrito Sobre o conceito de doutrina da ciência (GA, I, 2, p. 151) e na Grundlage der gesammten Wissenschaftslehre (GA, I, 2, p. 425).

${ }^{27}$ Evidente, nesse sentido, o débito para com Rickert e, em particular, para com Der Gegenstand der Erkenntniss (RICKERT, 1892), cuja discussão não pode ser aqui enfrentada.

${ }^{28}$ Sobre esse tema, cf. Rametta (2002).
} 
1984, p. 60). Isso não vale para Lask, nem tampouco para Fichte. Nos dois autores, entrevê-se, antes de mais nada, a exigência de autolegitimar o discurso filosófico (que, enquanto tal, deve prescindir de uma relação direta com o mundo factual), proceder de lado a lado à definição da modalidade, através da qual o discurso filosófico mesmo pode incidir sobre o real (termo ao qual a filosofia deve necessariamente retornar). ${ }^{29}$

\section{O IRRACIONAL COMO PROBLEMA}

Aparentemente, o Fichte-Buch de Lask se apresenta como um trabalho acadêmico, plenamente inscrito no contexto da escola de Baden e alinhado com as posiçóes de seus maiores expoentes: Windelband, Liebmann e Rickert. ${ }^{30} \mathrm{O}$ confronto com esses personagens permite destacar e isolar três aspectos da leitura laskiana importantes para compreender o sentido geral, a originalidade e a fecundidade dela: o papel de Fichte no desenvolvimento da problematização da história e da irracionalidade (Windelband), o seu antipsicologismo (Liebmann) e a centralidade da relação entre filosofia e vida, no seu desenvolvimento filosófico (Rickert).

No que diz respeito ao título dado por Lask à sua tese, Fichtes Idealismus und die Geschichte, nota-se uma certa e aparente desproporção entre Idealismus e Geschichte. Grande parte do livro se ocupa de determinar a evolução teórica da WL (o Idealismus de Fichte), enquanto só a última seção do texto, sessenta páginas de cerca de 230, expóe a filosofia fichtiana da história (isto é, a Geschichte). ${ }^{31}$ Ao concluir a sua longa introdução, Lask adverte o leitor de que "a parte mais ampla desta pesquisa deve ser vista só como trabalho preliminar (Vorarbeit), e não obstante como a operação mais importante e difícil para dar uma apresentação da lógica fichtiana da história e da cultura" (FI, p. 19). A filosofia da história vem, assim, exposta em um Ausblick (FI, p. 20), ou seja, em uma visão global que se apresenta como implicação direta da exposição dos

\footnotetext{
${ }^{29}$ Para uma visão global do retorno à vida da WL cf. Ivaldo (1997) e Lauth (1965).

${ }^{30}$ Tal contextualização não pode, nem quer, ser exaustiva. A tese laskiana dá uma ideia dos problemas com que se comprometia a pesquisa sobre Fichte, nos primeiros anos do século passado. Lask fornece, além disso, um quadro global da leitura de Fichte realizada na época. O exame desses elementos é, no entanto, tema de um trabalho à parte. Para uma ideia sobre a penetração do pensamento de Fichte no neokantismo, cf. Köhnke (1991).

${ }^{31}$ Em realidade, o título mesmo tem um caráter equívoco, o qual indica não tanto um percurso que reflete sobre o idealismo e sobre a filosofia da história de Fichte, porém, esclarece como o idealismo fichtiano incide sobre a compreensão da história como problema geral.
} 
pressupostos lógico-epistemológicos necessários para compreendê-la, a qual deve desenvolver-se na forma de uma análise abrangente do desenvolvimento da filosofia pós-kantiana $\left(F I\right.$, p. 19). ${ }^{32}$

A preponderância da parte preparatória pode ser compreendida prestando-se atenção à primeira nota do texto, dedicada a Windelband. A premissa de Lask é o resultado de Windelband: ${ }^{33}$ a exibição da profunda interligação entre a definição da essência crítica da filosofia e a compreensão da história segundo uma metodologia que se afasta daquela das ciências naturais. ${ }^{34}$

A oscilação entre esfera temática e metanível (isto é, entre visão da história e definição do método de pesquisa sobre a história) representa, segundo Lask, a pointe do idealismo alemão. A pergunta "como fazemos para atribuir um sentido à história?” envolve uma reflexão sobre a possibilidade de alcançar

32 O livro de Lask, que reproduz a tese defendida em 1902, teve duas edições, em 1903 e em 1923, e foi republicado, em 2002, no primeiro volume de uma reedição das Sämtliche Werke laskianas. O texto, que na edição das Sämtliche Werke consiste em 228 páginas, compôe-se de um prefácio, de uma introdução e de três partes. A primeira é dedicada a determinar os pressupostos lógicos do racionalismo de Kant e Hegel e a posição de Fichte no desenvolvimento da especulação alemã. Lask trata-a em três capítulos dedicados respectivamente à lógica kantiana, à hegeliana e a uma descrição preliminar do percurso fichtiano. A segunda parte tem como escopo a descrição do racionalismo de Fichte e da função que, neste último, ocupa a concepção da irracionalidade do empírico. O discurso é dividido novamente em três grandes seçōes. A primeira descreve o pensamento fichtiano de 1794 a 1797, a segunda considera a fase que vai de 1798 a 1801, e a terceira, os anos 1801-1804. A terceira parte do volume apresenta a filosofia da história fichtiana, a qual é analisada em dois momentos. Uma tem a ver com uma descriçẫo do ponto de vista fichtiano de 1805, exposto por Fichte nos Grundzüge dês Gegenwärtigen Zeitalters. A outra trata, ao invés, do Fichte das Reden an die Deutsche Nation e da Staatslehre.

${ }^{33}$ Lask cita três ensaios presentes na coleção Präludien: Immanuel Kant, Kritische oder genetische methode? E Was ist Philosophie? A escolha, como veremos, não é sem significado.

${ }^{34}$ Nos ensaios citados por Lask, Windelband sustenta que as afirmações filosóficas e históricas podem ser fundadas sustentando a legitimação dos dados empíricos através de uma reflexão que se move a partir dos fatos até uma consideração da "validade" deles, em função de uma interpretação em chave teleológica (WINDELBAND, 1907, p. 113 ss). A atribuiçáo do sentido (filosofia) a um evento (história) ocorre relacionando o evento particular a um valor geral (WINDELBAND, 1907, p. 24-25). Desse modo, a autolegitimação da filosofia e a reflexão sobre a história ligam-se de maneira inseparável e representam dois aspetos de um mesmo processo: a substituição kantiana do quid juris ao quid facti. Kant apresenta-se, assim, como o fundador de uma nova filosofia da história que sabe distinguir entre método explicativo, o genético e método wertbeurteilend, ou crítico. Mas também a Fichte são atribuídos ao menos dois métodos fundamentais. O primeiro consiste no enfatizar o plano metateórico presente na $W L$ : o desenvolvimento da filosofia procede de braços dados com a legitimação do método crítico (WINDELBAND, 1907, p. 125). O segundo consiste no fato de que a história pragmática do espírito humano fichtiana pode ser entendida como definição daquela que Windelband chama "consciência normal", portanto, definição da relação entre as determinaçôes empíricas da consciência e os valores universais que conferem seu sentido (WINDELBAND 1907, p. 126). 
um esclarecimento sobre a natureza do que chamamos evento ou fato. Falar de um sentido da história, afirmar que alguns objetos são "históricos", significa estabelecer relação com uma dimensão de sentido "outra" do histórico, mesmo quando se observa que, na verdade, todo objeto que é dado o é somente enquanto ele pode entrar na história. A posição de Fichte encarnaria, de acordo com Lask, perfeitamente essa flutuação entre atenção ao fato e exigência de um termo universal que lhe dá sentido. A $W L$ procuraria um fator racional universal por meio de uma compreensão da dinâmica transcendental do saber. No entanto, tal compreensão não poderia acontecer sem alcançar a função decisiva da individualidade histórica, nesse processo. A individualidade não é, na interpretação de Lask, uma "exemplificação" do fator universal, mas o lugar ou, por assim dizer, a função, em que o universal se concretiza e se enriquece. ${ }^{35} \mathrm{O}$ indivíduo é realidade viva e irracional, capaz de rearticular a esfera do valor e traduzi-la em uma ação legítima (e, portanto, sensata) que modifica racionalmente o mundo $(F I$, p. 169) e concretiza uma "força que reorganiza o sistema inteiro" (FI, p. 120).

Confrontado com Kant e Hegel, Fichte é então considerado por Lask como o protagonista "de uma tomada de consciência da especificidade lógica do histórico”, uma operação diversa e muito menos conhecida da metafísica da história que aborda em obras como o Gründzuge, o Reden ou a Staatlehre (FI, p. 19), e colocado entre Kant e Hegel, ou seja, entre dois modelos que tentam inscrever o individual no horizonte da razão. No modelo kantiano, que Lask chama "lógica analítica", o plano empírico é a única realidade possível, contraposta ao conceito, entendido como algo produzido exclusivamente pelo pensamento e desligado da dimensão empírica do conhecimento. Alternativa a esta é a "lógica emanatista", típica de Hegel, a qual pressupóe a prioridade lógica do conceito, da qual segue, como sua parte integrante, a inteira dimensão da Wirklichkeit.

Para Lask, a lógica de Kant seria coerente com um racionalismo absoluto (FI, p. 20-21), pois a suposta síntese kantiana se tornaria, na verdade, uma mera aplicação. O criticismo, conforme Lask, transforma a relação entre ser e conhecer na conexão imanente entre regra da consciência (conceitos) e casos da regra mesma (objetos empíricos). Estes últimos são concebidos, é certo, como objetualidade, mas nunca como objetos realmente existentes para

${ }^{35}$ A compreensão da relação entre universal e individual, nesse sentido, é apresentada por Fichte de maneira muito clara nas liçóes sobre Tatsache ndes Bewusstseyns, de 1810-11, por exemplo em GA (II, 11, p. 136-141), ou na Sittenlehre 1812, (GA, II, 12, p. 348), sobre a qual cf. respectivamente, Ferraguto (2014), e Ivaldo (2006). 
o conhecimento. Do ponto de vista lógico, as individualidades empíricas são contingentes e permanecem, assim, irredutíveis e irracionais (FI, p. 25, 27, 29). Entre conceito e individualidade existe uma separação absoluta: a individualidade pode sempre ser compreendida como exemplo do conceito; mas o preço dessa interpretaçáo será sempre o sacrifício de sua particularidade e de sua irrepetibilidade.

De acordo com Lask, a lógica de Hegel atribui, ao contrário, à individualidade uma função decisiva ( $F I$, p. 46). Essa é parte integrante do conceito, ela o enriquece e é compreensível como seu membro ou emanação. É o conceito, ou espírito absoluto, a determiná-la e legitimá-la como existência concreta (Wirklichkeit) e a dar-lhe sentido. Não obstante possa ainda ser reinserida no âmago do racionalismo absoluto de cunho kantiano, a lógica emanatista testemunha uma atenção inaudita pela individualidade, a qual reitera constante e fortemente a efetividade.

$\mathrm{Na}$ interpretação de Lask, lógica analítica e lógica emanatista não são alternativas, mas representam duas fases de um mesmo processo de aprofundamento da visão crítica kantiana em que se visa à eliminação progressiva da coisa em si. Antes de Lask, essa passagem é recuperada pela síntese fornecida por Windelband, no parágrafo 69 da sua História da filosofia moderna, explicitamente dedicada ao irracionalismo na filosofia clássica alemá. Aqui, Windelband salienta, referindo-se ao criticismo:

A imagem do mundo na cabeça do homem, condicionada pela razão, é um fenômeno de cuja relaçáo com a realidade nada podemos saber. Como queda do conceito de coisa e, com efeito, desta restriçáo crítica, a filosofia voltava a esta concepção racionalista. Este processo foi acentuando-se sempre mais até Hegel tornar o idealismo kantiano em um racionalismo absoluto. (WINDELBAND, 1925, p. 186-187).

O passo decisivo nesse sentido não é realizado por Fichte, porém, por Maimon. ${ }^{36}$ Segundo Windelband, Maimon compreende pela primeira vez o conceito de coisa em si, graças a uma formulação matemática, que a entende como raiz quadrada de 2 , isto é, como grandeza imaginária, como tarefa inexecutável no plano transcendental e, portanto, como irracional. Com efeito, segundo Maimon, "temos consciência apenas do que se encontra em nossa consciência”. Também na interpretação de Lask, a equação maimoniana entre

${ }^{36}$ Maimon (1965, p. 38) nega a possibilidade de integrar particular e universal, por exemplo, nos Streiferein im Gebiete der Philosophie. 
matemática e absolutidade epistemológica da filosofia transcendental assinala a passagem da lógica analítica àquela imanentista. A matemática, na verdade, permite prescindir daquilo que é irracional. E ainda que em seu nível de investigação "o objeto intuitivo seja singular, concreto, dado", isso se dá "a priori e não a posteriori como o material da sensação; isso é - unicum lógico! - individual, irrepetível, portanto construível ao mesmo tempo que a priori" (FI, p. 33).

Conforme a interpretaçáo laskiana do desenvolvimento da filosofia clássica alemá, que acabamos de apresentar, a reflexão sobre o problema da história e a compreensibilidade da individualidade histórica ficaria, assim, contido entre duas opçóes. A primeira negaria a possibilidade de um conhecimento da individualidade histórica e a declara certamente como irracional (Kant-Maimon) (FI, p. 33 e 206). A segunda, ao contrário, encarregar-se-ia do irracional, mas o traduziria matematicamente em um desenho absolutamente racionalista (Hegel) (FI, p. 47-48). A individualidade histórica torna-se, portanto, ou um termo epistemologicamente absurdo ou um átomo de uma molécula da qual não poderá nunca ser sensatamente desarticulada.

\section{Fichte: A ALTERNATIVA}

Nesse contexto geral, Lask coloca Fichte. Para Lask, o filósofo de Rammenau emprestaria de Kant uma concepção do histórico como empírico (FI, p. 54-55). O passo essencial da WL além de Kant consistiria, no entanto, em mostrar a inevitabilidade do fator empírico para a concretização do geral. A Wirklichkeit do histórico não estaria contraposta à generalidade do conceito, mas se tornaria, em analogia com a lógica hegeliana, um momento essencial do desenvolvimento do conceito mesmo (FI, p. 55).

Diferentemente do modelo kantiano e do hegeliano, Fichte representaria uma "terceira via". De acordo com Lask, a WL de Fichte tentaria conciliar as duas lógicas e evidenciar seus pontos excedentes. $\mathrm{O}$ percurso fichtiano significaria, portanto, uma inversão de tendência do desenvolvimento histórico do idealismo alemão: não mais de Kant a Hegel, mas de Hegel a Kant (FI, p. 65), ou seja, da lógica emanatista à analítica, no sentido de uma concepção que Lask, na esteira de Rickert, define ainda como positivista. 
Para Lask, o desenvolvimento da filosofia fichtiana se desdobra em três fases. A primeira coincide com o ponto de vista assumido na Grundlage der gesamten Wissenschaftslehre, em 1794. Nessa primeira exposição da WL, Fichte antecipa a forma emanatista da lógica, a qual será depois elaborada por Hegel. A segunda começa com as Einleitungen publicadas no Philosophiches Journal (1797-1798) e se estende até o Sonnenklarer Bericht (1801). Nessa segunda tentativa, Fichte busca separar a forma e o conteúdo da subjetividade e da filosofia, capitalizando as críticas de Maimon e tentando aproximar-se da lógica analítica kantiana. Em uma terceira fase, que culmina na segunda exposição da WL de 1804, Fichte trabalharia sobre os pressupostos de uma teoria da história baseada em uma epistemologia de tipo kantiano transposta num plano metafísico. Desse trabalho derivaria a teoria da história exposta nos Grundzüge des gegenwärtigen Zeitalters, a doutrina da religiáo da Anweisung, a teoria da ação política apresentada nos Reden e a reflexão sobre a revelação, que fica central na Staatslehre.

O critério assumido por Lask para distinguir as diversas fases do pensamento de Fichte é a determinação de sua posição, no que diz respeito ao problema da irracionalidade. ${ }^{37}$ Tais variaçóes legam a esse tema ao menos mais duas questóes: aquela da coisa em si e aquela relativa à relação entre filosofia e vida (FI, p. 99).

A cifra do emanatismo da Grundlage é dada, segundo Lask, pelo terceiro princípio da WL: eu contraponho, no eu, "ao eu divisível um náo-eu divisível" (FI, p. 64). Nessa formulação, dá-se uma preeminência ao eu, que é aquele mesmo eu absoluto de que Fichte fala no primeiro princípio da $W L$, o qual, por sua vez, é entendido como o fundamento de todas as determinaçôes concretas da consciência derivadas do terceiro. Assim, o princípio geral do idealismo se amalgama à afirmação, conforme o empírico é dominável graças a uma dialética especulativa (FI, p. 65). A Ichheit do eu absoluto torna-se idêntica a um eu efetivo que póe, isto é, produz, o objeto contraposto a ele. ${ }^{38}$ Essa passagem comporta, segundo Lask, duas consequências. A primeira é que, na $W L$, o eu e o saber são considerados como os conceitos filosóficos mais elevados. Esses são abstrações que indicam que tudo aquilo que é não pode ser senão para o eu e, portanto, deve sempre ser Ichaft. A segunda é que a generalidade transcendental

\footnotetext{
${ }^{37}$ A questão clássica da divisão do pensamento de Fichte em duas ou até três fases é discutida por Pareyson (1976).

${ }^{38}$ Esse esquema interpretativo da doutrina fichtiana do eu absoluto e da sua relação com o eu concreto é retomado por Zöller (2012).
} 
do eu absoluto é identificada com um conceito de totalidade do qual derivam dialeticamente a individualidade singular histórica e epistemológica. A Ichheit, que reflete o primado do saber, aparece também como uma generalidade transcendental que se nutre ao mesmo tempo da Wirklichkeit do não-eu, a qual é compreensível só em função do eu mesmo (FI, p. 71).

À luz dessa interpretação da primeira parte da Grundlage, Lask entende a $W L$ como um panlogismo no qual se misturam motivos metafísicos e motivos transcendentais. ${ }^{39}$ Central nessa interpretação é a tensão entre uma compreensáo do eu absoluto como forma da reflexáo e, ao mesmo tempo, como ideia que ultrapassa a empiria. Trata-se de uma oscilação hermenêutica que reflete a crítica formulada por Windelband a Fichte, no ensaio Kritische oder genetiche methode?, no qual Windelband vê a lógica da Grundlage como um método dialético que determina tanto os propósitos quanto os meios para realizá-la. Os propósitos seriam constituídos conjuntamente com os valores que tornam a filosofia uma investigação que não vislumbra os fatos, mas a validade de sua fundação. E os instrumentos não seriam os objetos, mas as concretas determinaçóes cognitivas que devem ser fundamentadas (WINDELBAND, 1907, p. 126-127). Por esse motivo, a posição fichtiana resulta, aos olhos de Lask, insuficiente. Fichte, em verdade, não falharia em determinar a esfera dos valores como um horizonte autônomo. A definição da esfera do valor reproduziria o modelo da investigação sobre o ser, o que, tanto para Windelband como para Lask, é absurdo.

Essa complicação de motivos transcendentais e motivos metafísicos representa, segundo Lask, o germe da dissolução do imanentismo de Fichte. O ponto de vista assumido a partir de 1797, em verdade, tende a distinguir rigorosamente o eu como forma geral do saber, que se obtém através da abstração feita da consciência, e o eu como ideia, que se apresenta como o terminus ad quem do aperfeiçoamento prático do ser humano. ${ }^{40}$ A qualquer um dos dois polos é correlata uma diversa noção de irracionalidade.

No caso do eu como forma geral do saber, a irracionalidade é, com Kant, um limite radical e contingente do conhecimento. Entretanto, tal limite não pode ser kantianamente entendido como coisa em si. $\mathrm{Na}$ verdade, já na

\footnotetext{
${ }^{39} F I$ (p. 71), onde Lask interpreta a primeira exposição da doutrina da ciência de 1794 como uma "mistura confusa de variados motivos metafísicos e epistemológicos (erkenntistheoretischen)".

${ }^{40}$ Central é a funçấo do $\$ 11$ da Zweite Einleitung in die Wissenschaftslehre, na qual Fichte se dedica justamente a discutir a sonderbare Verwechselung entre o eu como intuiçáo intelectual e o eu como ideia (GA, I, 4, p. 265).
} 
Grundlage, Fichte havia mostrado como todas as determinaçóes cognoscitivas devem ser compreendidas não como relaçóes a um objeto externo transcendente à consciência, mas em relação a um poder de autolimitar-se que o eu subscreve a si mesmo. O eu como forma geral do saber precede, por conseguinte, a individualidade e encarna a exigência de uma limitação originária.

O eu como ideia, ao invés, ultrapassa e se liberta da individualidade. A ideia é irracional, porque ultrapassa a forma do saber discursivo que, tanto para Fichte como para Lask, proporciona ao indivíduo como sua condição. $\mathrm{O}$ nexo que junta as duas dimensóes e que representa igualmente a chave que abre a Fichte a porta da filosofia da história é, na opinião de Lask, o fato de que o eu como ideia, justamente porque é diverso do abstrato e atemporal eu como forma, pode ser concretamente realizado nele. $\mathrm{O}$ eu como ideia torna possível, portanto, uma concepção do tempo que permite pensar concretamente (isto é, como realizável) uma racionalidade absoluta, a qual, no entanto, não pode ser reduzida a correlato de um saber puramente formal. Fichte, desse modo, não pode mais ser emanatista, porque forma do saber e concretude da razão se cindem. Porém, ele não pode ficar nem sequer racionalista, pois, diferentemente de Kant, a ideia não é forma, mas concreção que se obtém no tempo. A posição de Fichte seria o antirracionalismo crítico: a irredutibilidade do individual aparece como um limite da razão e abre, ao mesmo tempo, a uma ideia que lhe confere sentido sem coincidir com ela. Essa passagem é cheia de consequências, tanto na leitura de Fichte como no desenvolvimento do pensamento de Lask (FI, p. 75).

A diferença entre o eu como forma do saber, o eu como indivíduo e o eu como ideia resume a posição de Fichte, seja no que diz respeito da leitura de Windelband, seja quanto às possíveis interpretações psicológicas da WL e, sobretudo, aquela de Liebmann, autor de Kant und die Epigonen (FI, p. 83; LIEBMANN, 1990, p. 73-75). A partir dos resultados de Lask, na verdade, a interpretação de Windelband não se revela completamente legítima. Apesar de ter razão quanto à periodização da filosofia clássica alemá e à colocação do pensamento fichtiano no seu contexto, Windelband se limita a ver na WL um aprofundamento da perspectiva kantiana e, portanto, uma reconsideração unidimensional do racionalismo em chave emanatista. Lask amplia e inverte a interpretação, mostrando como a centralidade do problema do irracional é um instrumento para avaliar as mudanças internas à perspectiva de Fichte e, ainda, para determinar a posição de Fichte em toda a sua autonomia, bem além do percurso, inteiramente racionalista, que de Kant conduz a Hegel. A passagem 
da fase de 1794 à que se inicia em 1797 evidencia, em verdade, como o eu de Fichte náo seria transcendente do mesmo modo que a coisa em si (como queria Liebmann). Em vez disso, o eu é um conceito crítico. Possui sentido exclusivamente como determinação do saber e só enquanto tal pode ser também compreendido como "acima do espaço e tempo e das categorias" (FI, p. 82). $\mathrm{O}$ eu é atividade que compreende a si mesma, contudo, nessa compreensão, não se entende como um objeto, porém como atividade mesma da razão a qual se expóe através do saber, isto é, como articulação coerente da exigência de justificação absoluta que define a razão enquanto tal.

A última e mais importante consequência dessa argumentação laskiana é que a relação entre eu como ideia e eu como forma, correlata às duas perspectivas sobre a irracionalidade, desdobra o plano da filosofia da história. A $Z u$ fälligkeit kantiana é progressivamente transformada em determinidade (Bestimmtheit) do eu e em determinação (Bestimmung) do eu mesmo. O princípio do agir não é mais aquele kantiano: "age segundo a máxima de tua razão", mas: "age segundo a tua Bestimmung". O indivíduo, de termo negativo e não conceituável, torna-se força positiva capaz de atravessar, ultrapassando-a, a esfera da razão judicativa e realizar ao longo do tempo uma ideia que, para Fichte, é radicalmente supraindividual. A passagem da dimensão empírica da individualidade àquela em que o agir individual é compreendido como Bestimmung, isto é, como agir concreto dotado de valor, consagra, em Fichte, a diferença entre Historie e Geschichte: conjunto empírico de eventos e compreensão desses mesmos eventos como orientados teleologicamente para um valor. ${ }^{41}$

As diversas fases de amadurecimento de uma filosofia da história que Lask encontra no pensamento de Fichte são condicionadas por esse movimento. No caso da primeira filosofia da história, aquela dos Grundzüge, o plano supraindividual é ainda de molde iluminístico e foca na teorização de um Estado de razão substancialmente desligado do agir do indivíduo concreto. Todavia, no caso da filosofia posterior a 1805, o antirracionalismo fichtiano se exprime na tentativa de conceber uma individualidade que, ao mesmo tempo, é totalmente concreta e exibe potencialidades que transcendem o seu ser particular. O conceito de nação elaborado nas Reden an die Deutche Nation lida com essa exigência. A nação alemã presente nas Reden fichtianas não é só aquela descrita no concreto ato dos discursos. Os alemães são também eles mesmos os que respondem ao apelo formulado por Fichte e, nessa resposta, se

${ }^{41}$ Cf. a passagem da V lição dos Grundzüge des gegenwärtigen Zeitalters (GA, I, 8, p. 301). Sobre a questão, ver também Ivaldo (1995). 
tornam expressão de um Si livre e capaz de expandir a razão da ação de uma comunidade, renunciando, ou colocando em comum, aquilo que é mais propriamente seu (ZÖLLER, 2008).

A resposta política requerida pelas Reden, portanto, faz a história, porque torna os alemáes responsáveis pelo próprio destino e pelo da Europa inteira. A resposta ao apelo à renovação formulado nos Discursos cria conexóes alternativas de valores que transcendem as suas dimensôes geográficas ${ }^{42}$, fazendo-se portadoras de uma ideia do humano, a qual, enquanto se concretiza em uma individualidade histórico-efetiva, tem valor universal. A nação alemã faz também a política, porque não a reduz a uma atividade particular na esfera do Estado, mas a contempla como um reflexo da essência mesma do humano. A nação alemã faz, por fim, a filosofia, porque o seu agir é o reflexo de um saber cuja realização não é um conjunto de declarações rarefeitas e autorreferenciais, contudo, constitui uma exortação a uma modificação efetiva do mundo. Em Fichte, o âmbito dos valores, assim como a inteira esfera das realizaçóes que pertencem ao gênero humano, não resulta de uma abstrata indeterminação do pensamento, mas se desenvolve através de um fluxo valorativo que se estende acima das geraçóes e chega à consciência no momento em que os indivíduos singulares sejam considerados portadores (FI, p. 149 ss).

Por isso, Lask encontra em Fichte uma perspectiva cuja exigência lógico-epistemológica de alcançar uma validade absoluta acerca da forma e dos elementos do saber vem a conjugar-se com um pensamento da história capaz de abrir espaço ao concreto agir da individualidade. A interpretação de Lask tem o mérito de evidenciar como a legitimação desse movimento aparece na radicalização da dimensão antirracionalista do pensamento fichtiano que se desenvolve entre 1797 e 1801 e culmina no Atheismusstreit. Como veremos no parágrafo seguinte, a interpretação de Lask não apenas fica fiel ao espírito da doutrina da ciência de Fichte, mas fornece instrumentos linguísticos e conceituais muito proveitosos para compreender o pensamento fichtiano como tentativa de dar conta, assim como Fichte escreve na $W L$ de 1812, do "inteiro sistema da facticidade" (GA, II, 13, p. 59).

\footnotetext{
42 Pode-se ler aqui uma antecipação da interpretação da filosofia de Fichte dada por Husserl, nas liçóes sobre o Fichtes Menscheitsideal cf. em part. (HU, p. 277-278). Sobre esse aspecto do pensamento de Fichte, cf. ÖSTERREICH, 1990. Sobre a relaçáo entre Fichte e Husserl, cf. Ferraguto (2008), Labib (2011), Dedeurawaerdere (2008). Uma interpretação da ideia de nacionalidade como caráter essencial da subjetividade e dada por Derrida (2001, p. 83).
} 


\section{Filosofia E VIDA}

Segundo Lask, a partir de 1797, Fichte tentaria "extirpar o asilo transcendente da irracionalidade" e ligar essa operação ao desenvolvimento de uma concepção dinâmica da individualidade histórica. A sua pesquisa aponta inicialmente contra aqueles sistemas filosóficos que identificam as determinaçóes da consciência com os seus produtos, em função das leis da lógica formal. Esta era a perspectiva de Beck, a qual Fichte critica, na Erste Einleitung, como suporte de um "idealismo lógico". Em levar adiante sua crítica, Fichte investiga as formas gerais do saber à luz das quais os seus componentes não são discursivos. De fato, esses componentes, mesmo permanecendo imediatos, assumem uma função insubstituível no desenvolvimento da visão transcendental. A descrição da constituição psicológica e antropológica da consciência concreta exibe a função categorial dos mesmos fatores que qualificam a concretude. ${ }^{43}$ Dito de maneira mais simples: a WL deve esclarecer como aqueles elementos não diretamente reconduzíveis ao conceito (por exemplo, impulso, sentimento, sensibilidade etc.) são em realidade elementos constituintes, ou portadores, da esfera complexa da conceitualidade. ${ }^{44}$ Lask teria tido uma vida fácil, ao esclarecer esse ponto, se tivesse tomado conhecimento das liçôes sobre a Wissenschafstlehre nova methodo (cuja primeira edição foi publicada apenas quinze anos após a primeira edição do Fichte-Buch). Nesse curso, coevo às introduções de 1797, Fichte acentua efetivamente a descrição da consciência concreta no propósito de fornecer uma base teórica a textos que, ao invés, eram muito conhecidos na época, tais como como o System der Sittenlehre nach den Principien der Wissenschafstlehre (1798) ou a Grundlage des Naturrechts nach den Principien der Wissenschaftslehre (1797).

De maneira coerente com a ideia da WL como saber do saber, essa operação está ligada à definição metateórica da relação entre filosofia e vida. O problema é particularmente urgente. A recepção da $W L$ era, em verdade, saturada de leituras - como as de Hölderlin, Nicolai, Baggesen, Jean Paul, Jacobi - que atribuíam à WL uma espécie de "spinozismo invertido", ou que compreendiam o eu fichtiano como um absoluto criador do mundo por força da própria autoatividade ideal. ${ }^{45}$ Eram leituras que, como se pode bem ver,

\footnotetext{
${ }^{43}$ Para uma contextualização histórica dos motivos que levam Fichte a realizar essa passagem, ver Fabbianelli (2000).

${ }^{44}$ Uma fundamental contribuição à pesquisa sobre esse aspecto do pensamento de Fichte, que confirma a exigência laskiana, é dada por Cesa (1993), Cesa (2002) e Cesa (2007).

45 Exemplar, nesse sentido, é a interpretação dada pelo poeta dinamarquês Baggesen, em Baggesen (1831, p. 241, 216-217).
} 
antecipavam, facilitavam e conduziam a identificação da $W L$ com o niilismo (IACOVACCI, 1992).

Fichte opta, então, por uma mais drástica e evidente separação entre filosofia e vida, a qual se reverte, na marcada valorização dos fatores extrafilosóficos, na efetivação do filosofar (BREAZEALE, 2007). A leitura de Lask recupera esse movimento, de maneira táo forte, que o induz a falar de positivismo. Para a $W L$ desses anos, em verdade,

existe só isto que pode ser visto imediatamente e na sua plena determinação, nunca reconduzível a um sistema de conceitos; acima deste elevam-se apenas as formaçóes da abstração. Em contraste está a realidade empírica, mas náo como um reflexo imperfeito, de grau ontologicamente inferior, mas como ponto de partida dado, como a base única e irregressível [...] As tendências empíricas e nominalísticas culminam em um positivismo extremo. (FI, p. 106).

Uma interpretação muito similar a esta é dada por Rickert, em 1899. Diferentemente da teoria kantiana dos dois mundos, o Fichte do Atheimustreit seria intérprete de uma separação total das esferas do ser (empírico e supraempírico). Isto que primeiramente é entendido como antimetafísico (ou, nos termos de Lask, antirracional), agora se torna, "se assim se quer, positivista, uma vez que não poderia ser diferente a quem compreendeu a analítica transcendental kantiana" (RICKERT, 1899, p. 20). Obviamente, o positivismo de Fichte resulta muito distante de uma absolutização do dado empírico, assim como isso pode ser formalizado na visão da ciência moderna ou como teria podido entender o Schelling da Philosophie der Offenbarung. Fichte visa, pelo contrário, a polemizar contra o racionalismo wolffiano, isto é, contra aquela perspectiva que, como também explica Lask, troca as formas da consciência com realidades absolutas. Fichte leva adiante essa sua ideia, aprofundando os resultados da analítica kantiana e trazendo à tona uma separaçáo clara entre as formas da consciência e a Wirklichkeit do dado do conhecer. A irracionalidade do individual - a irredutibilidade do efetivo à forma conceitual - é, portanto, inclinada a uma função decisivamente crítica ou, por assim dizer, antidogmática, seja porque elimina da definição da filosofia todos os elementos não assimiláveis à filosofia mesma, seja porque elimina da visão da vida todos aqueles fatores transferíveis incondicionalmente da filosofia. 
A transformaçáo "positivista" da WL representa agora a premissa para uma noção de Wertindividualität que, contra o emanatismo hegeliano e plenamente em linha com Rickert, é introduzida para salvar a autonomia do individual e atribuir-lhe uma função positiva na determinação do valor.

Em Lask, no entanto, individual e irracional não coincidem perfeitamente. $\mathrm{O}$ individual não é sempre irracional. $\mathrm{O}$ irracional excede a esfera da individualidade e pode ser assimilado ao dado sensível-intuitivo. E irracionais são também a dimensão alógica da consciência e a esfera do agir e do conhecer, ou seja, a matéria originária da formação lógica, independente de todo ser vivente, cognoscente e agente. Fichte teria posto as premissas para essa conclusão, mostrando como todo conteúdo singular da consciência seria ao mesmo tempo irredutível e portador de um valor que não lhe é atribuído exclusivamente na esfera do saber.

A partir dessa premissa, a relaçáo entre filosofia e vida pode ser explicada com base em três perspectivas que envolvem três aspectos fundamentais da WL como ideia global da filosofia: primado do prático sobre o teórico; função da imediatidade no conhecimento e no agir; busca e dedução dos pressupostos epistemológicos que proporcionam essas passagens.

Como já explicava Rickert, a unificação fichtiana de filosofia teorética e prática, em vista da afirmação do primado do prático sobre o teórico, pressupóe a reflexão sobre a irredutibilidade do sentimento à compreensão conceitual. O sentimento é percepção imediata de si, e é também portador de uma certeza imediata de si mesmo (RICKERT, 1899, p. 8). O critério da verdade não é mais externo ao eu e não é nem mesmo uma lei que o transcende plenamente. A verdade depende imediatamente do sujeito concreto: o fato de que eu duvido ou tenha algo por certo não está dado por uma argumentaçáo, mas por um sentimento imediato. Só enquanto eu sou um ser moral, a certeza torna-se possível para mim, porque o critério de toda a verdade teorética não é novamente qualquer coisa de teorética, mas qualquer coisa de prática. (RICKERT, 1899, p. 8).

A "letra" de Fichte é coerente com essa interpretação e, ainda, estabelece uma conexão estreitíssima entre o esclarecimento do primado do prático e a marcada separação entre filosofia e vida. Em uma série de anotações de 1800, intituladas Rückerinnerungen, Fragen, Antworten, náo por acaso tida em grande consideração por Lask e por Rickert, Fichte escreve: 
Se, portanto, a realidade de um conhecimento deve ser demonstrada pela filosofia ou pelo raciocínio, é preciso que seja indicado um sentimento [...] ao qual este conhecimento se vincule diretamente. $\mathrm{O}$ raciocínio livre pode somente penetrar, esclarecer o conteúdo, dividir e coligar a multiplicidade [...], mas não pode acrescentá-la, ampliar e tornar diversa a matéria. ( $G A$, II, 5, p. 138).

Lask comenta: só na medida em que o sentimento resulta irredutível ao conceito é possível pensar a individualidade como indicadora, ou portadora, de um valor. $\mathrm{O}$ valor é individual, porque não é englobado na forma do saber. O saber é separado da vida e a sua tarefa é apenas aquela de explicar a irredutibilidade dela em plena conformidade à célebre afirmaçáo fichtiana: "O viver é, em verdade, o não-filosofar; o filosofar é, em verdade, o não-viver.” (GA, II, 5, p. 124).

$\mathrm{O}$ Atheismusstreit, que motiva as anotaçóes de Fichte, não é importante somente porque impóe uma mudança, uma retificação ou um esclarecimento dos nexos da WL, mas também porque apresenta um problema que cruza o segmento biobibliográfico do filósofo de Rammenau, pondo a exigência de formular aqueles princípios de uma doutrina transcendental da religião, a qual Fichte ainda não havia escrito. Já Rickert entendia esse ponto crítico da filosofia transcendental assim explicando, sempre no seu ensaio de 1899:

A coisa fundamental em toda religiáo é [...] que não podemos alcançar uma ordenação suprassensível, isto a que a filosofia conduz com necessidade vinculante, também em uma relação pessoal. Mas uma relação que cria o próprio conteúdo por meio dos edifícios de uma metafísica não dará mais esta possibilidade, porque toda metafísica consiste de conceitos gerais, e do universal não podemos conquistar relaçóes pessoais. $\mathrm{O}$ espaço geral da metafísica deve agora ser necessariamente preenchido através das tradiçóes (Überlieferungen) de uma religião histórica. (RICKERT, 1899, p. 28).

O abandono da busca de conceitos gerais da divindade, sejam esses provenientes da metafísica, sejam da teologia, permite encontrar "no indivíduo o seu revestimento vivente [ihr lebendiges Kleid]" (RICKERT, 1899, p. 28); o que significa, conforme Fichte, que "o filósofo não tem um Deus e não pode tê-lo; ele tem, tão somente, um conceito do conceito da ideia de Deus. Deus e a religião existem apenas na vida [...] e é impossível que qualquer um seja apenas filósofo." (GA, II, 5, p. 130). Aos olhos de Rickert, Fichte aparece, por conseguinte, como "um dos primeiros fundadores de uma visão do mundo 
histórica” (RICKERT, 1899, p. 28-29). E Lask reconfigura essa interpretação rickertiana do pensamento de Fichte, remarcando um Stichwort der Glaubensphilosophie (FI, p. 113): a revelação (Offenbarung). o mesmo termo que, com referência à Staatslehre, resultará decisivo para interpretar a superação fichtiana do racionalismo que leva de Kant a Hegel. Lask ressalta:

$\mathrm{O}$ conceito no qual a unificação de valor e irracionalidade obteve uma expressão adequada, e sob qualquer aspecto conclusiva, é o conceito de revelação. Revelaçáo indica [...] uma tendência para a irracionalidade e, como anunciadora do divino, uma tendência para o valor absoluto. No pensamento da revelação a forma lógica do empírico-irracional se funde com o conteúdo do valor supra-empírico. (FI, p. 166).

Não se trata de estabelecer até onde os êxitos do pensamento de Lask podem implicar uma coincidência de cristianismo e filosofia. ${ }^{46}$ Interessante é, pelo contrário, notar como o conceito de Offenbarung é, tanto em Fichte como em Lask, a matriz de um movimento epistemológico que exige a formação de uma lógica diversa da lógica formal, uma lógica capaz de fazer frente ao problema da irracionalidade. ${ }^{47}$

\section{IMEDIATIDADE, SACRIFÍCIO E INDIVIDUALIDADE}

Com efeito, o ponto a respeito do qual Lask parece proceder para além de Rickert é o aprofundamento do teor epistemológico daquilo que o seu mestre entende como relação pessoal com a divindade. A possibilidade de uma valorizaçáo da individualidade se cinde, em Fichte, com o problema da imediatidade. Unmittelbar não é um alcance místico da vida, porém, o resíduo do saber. O imediato, escreve Fichte, "não agrega plenamente no conceito e, propriamente por isto, não pode ser precedido por algum conceito, mas deve ser necessariamente e imediatamente vivido" ( $G A$, II, 5, p. 138). A imediatidade coincide, portanto, com a facticidade do viver. A compreensão da facticidade não pode mais reduzir esse resíduo. Pode apenas assumi-lo conscientemente e na forma de um entregar-se despertado e observante a isto, que deve ser compreendido (FI, p. 165). Fichte tornará esse "entregar-se" (Hingeben)

\footnotetext{
${ }^{46}$ Para uma reflexão teórica sobre a coincidência de cristianismo e filosofia na filosofia clássica alemã, cf. Olivetti (1972).

47 Sobre a relação entre reflexão e crítica da lógica formal, que Fichte desenvolve sobretudo nas primeiras liçōes da primeira Transzendentale Logik de 1812, cf. Ivaldo (1998).
} 
um dos traços principais e iniciais da constituição do saber, sobretudo nos últimos anos de sua pesquisa, desde 1805 e, em maior medida, depois de 1808. Essa solução é, no entanto, prefigurada já no $\$ 8$ de Rückerinnerungen, Fragen, Antworten, onde é empregada para consolidar a distinção entre filosofia e vida, que, dessa maneira, pode ser reconduzida ao projeto geral da WL como definição dos princípios do saber. A vida, enfatiza Fichte,

é a totalidade do ser racional objetivo. A especulação é a totalidade do ser racional subjetivo. A vida, enquanto abandono ativo ao mecanismo, não é possível sem a atividade, e a liberdade (ou especulação), que se abandona (bingeben) e não alcança subitamente a clara consciência em cada indivíduo. (GA, II, 5, p. 119).

O Hingeben mantém juntas, separando-as, filosofia e vida. A imediatidade e a concretude se perdem, escrevendo-se no - ou entregando-se ao mecanismo reflexivo da especulação, ao propósito de compreender justificadamente a própria origem. Mas essa compreensão é por si mesma um gesto vital: agir, que livremente se dá ao outro de si qual seu fator constituinte. E, através desse seu dar-se, torna visível a sua constituição: liberdade, que tem sentido só em relação a isto que lhe é radicalmente outro. ${ }^{48}$

É a dinâmica do sacrifício, ou do entregar-se, que permite incluir o individual em um horizonte mais amplo que excede a racionalidade particular e se configura como operacionalidade geral da razão. Se o momento individual é a força irracional do empírico, a observação especulativa o insere em um processo teleológico que exibe progressivamente a dimensão valorativa. Se o momento individual é a Wirklichkeit necessária a esse ato de compreensão, o Hingeben intervém como autoconsciência do filósofo de ser intérprete de uma dimensão que ultrapassa aquilo que constitui o seu dever primário: acrescentar uma compreensão legítima e legitimante da vida (que, então, é irracional).

A formação de uma "lógica da lógica" (em Lask) ou de um "saber do saber” (em Fichte), implica, portanto, uma divisão infinita (e/ou circular) entre saber e vida, ou entre razão e irracionalidade. ${ }^{49}$ Tal divisão investe um con-

\footnotetext{
${ }^{48}$ Retoma-se aqui a reflexão sobre o sacrifício, feita por Marion (2008), em que, antes de investigar o sentido religioso ou existencial do sacrifício, o interpreta no sentido de uma Hingabe, ou seja, no de um dar disso, que é mais próprio, como condição de possibilidade para a formação da identidade do sujeito como constitutivamente ligado ao outro de si.

49 Para uma análise aprofundada das soluçôes linguísticas e conceituais adotada por Fichte para tratar essa divisão, sob o plano do desenvolvimento da WL em sentido estrito, cf. D’Alfonso (2014).
} 
junto de conceitos-limite que possibilitam distinguir o valor de um conceito abstrato e reencontrá-lo como elemento, para assim dizer, "em carne e osso". Nação, revelação, individualidade - estas as palavras-chave do Fichte-Buch laskiano - são conceitos-limite mediante os quais a separação entre filosofia e vida pode resultar definitiva. É possível, em verdade, considerar o conceito de nação como um elemento geral que recai em uma certa teoria política, e como aquele momento único que exibe uma relação pessoal e irredutível com Deus. É possível pensar a individualidade como termo negativo e contingente, o qual sobra do desenvolvimento de um saber que chega à autotransparência, e como pessoa singular, determinada, irrepetível. É possível, porém, pensar nação, revelação e individualidade como momentos em que a conceitualização filosófica se traduz em agir concreto: política, profecia, educação.

A reconstrução da interpretação laskiana do desenvolvimento da doutrina da ciência de Fichte, entre 1794 e 1801, apresenta, portanto, dois elementos que permitem destacar de uma maneira clara e justificada o modelo de incorporação do individual na razão, por meio do conceito de entrega, típica do antirracionalismo fichtiano e conceituada em toda a sua complexidade por Lask. Primeiro: a construção de um horizonte discursivo que, diferentemente dos racionalismos kantianos e hegelianos, autoriza pensar de maneira justificada o concreto agir da individualidade (cf. $\$ 5$ deste artigo). Segundo: a análise da relação entre filosofia e vida, na época do Atheismusstreit, assim como a comparação entre a interpretação de Lask e a de Rickert, facultam entender a individualidade não apenas como algo contingente, contudo, como algo que expressa um valor, cuja validade e constituição independe da atividade filosófica e se manifesta no viver do indivíduo particular.

Levado à sua extrema consequência, o transcendentalismo fichtiano parece poder pensar positivamente a divisão entre filosofia e vida, isto é, no quadro de uma reflexáo sobre a potencialidade praxiológica do indivíduo. E, por conseguinte, o transcendentalismo de Fichte parece implicar a formação de uma lógica em que a autorrealização do saber se traduz em uma modificação sensata do real. Mérito de Fichtes Idealismus und die Geschichte é ter trazido à luz esse nível da reflexão transcendental fichtiana, e tê-lo feito mediante uma conceituação que enriquece o próprio pensamento de Lask. Afinal, pode-se concordar com Paci, quando escreve que também Lask, "desde uma posição transcendentalista, desde uma filosofia, portanto, em que o ser parece reduzir-se ao conhecer [...] passa a uma filosofia em que contrariamente ao puro conhecer, se reestabelece o conceito de ser" (PACI, 1940, p. 57-58). 
O problema é, no entanto, compreender como e em que sentido a radicalização da disposição transcendental conduz à exigência de reestabelecer o conceito de ser. Poderia não ser um acaso que a parábola de autores como Fichte, Reinhold, Lask ou Husserl seja, de muitas maneiras, análoga.

\section{Abreviaçóes}

FI = E. Lask, Fichtes Idealismus und die Geschichte. Tübingen: Möhr 1903 (repr. Tübingen: Scheglmann, 2002).

GA = Johann Gottlieb Fichte, Gesamtausgabe der Bayerischen Akademie der Wissenschaften, hrsg. von R. Lauth, H. Jacob und H. Gliwitzky, Stuttgart-Bad Cannstatt: Frommann-Holzboog 1962-2013; I, Obras; II, Obras postumas; III, Correspondência; IV, Lições.

$W L=$ Wissenschaftslehre

FERRAGUTO, F. Sacrifice and individuality: Lask as a reader of Fichte. Trans/form/ ação, Marília, v. 42, n. 4, p. 125-156, Out./Dez., 2019.

ABSTRACT: This paper deals with the relationship between individuality and value in transcendental philosophy based on the analysis of J. G. Fichte's philosophy by Emil Lask in his 1903 book, Fichtes Idealismus und die Geschichte. The paper aims to demonstrate how the radicalization of transcendentalism guides it toward a non-empirical realism. It also aims to show how this non-empirical realism prevents transcendentalism from realizing itself exclusively in the form of self-reflexive investigation of the structures of consciousness, and translates it into an appreciation of praxis. After a discussion of Lask's philosophy in general and of Lask's Fichte-Buch $(\$ 2)$, I explain the content and development of Lask's thesis in relation to three specific authors: Windelband, Rickert, and Liebmann (\$3-4). Finally, I analyze two questions that are crucial to the development of Fichtean thought: the relationship between philosophy and life $(\$ 5)$ and between individuality and sacrifice $(\$ 6)$.

KeYworDs: Fichte. Lask. Neo-Kantianism. Transcendental philosophy. Individuality.

\section{REFERÊNCIAS}

AMERIKS, K. Kant and the fate of autonomy: problems in the appropriation of the critical philosophy. Cambridge: Cambridge University Press, 2000.

BARDILI, G. Grundriss der ersten Logik. Stuttgart: Loeflund, 1800. 
BAGGESEN, J. Aus Jens Baggesens philosophischer Briefwechsel mit K. L. Reinhold und F. H. Jacobi, 2 vol. Org. C. Baggesen. Leipzig, 1831.

BEISER, F. Historicism and neo-kantianism. Studies on History and Philosophy of Science, v. 39, n. 4, p. 554-564, 2008a.

BEISER, F. Emil Lask and kantianism. The philosophical Forum, v. 39, n. 2, p. 283-295, 2008 b.

BREAZEALE, D. "Der Blitz der Einsicht" and "Der Akt der Evidenz". Fichte-Studien, v. 31, p. 1-v. 15, 2007.

CARRINO, E. Emil Lask: filosofia giuridica, Napoli: ESI, 1984.

CESA, C. Fichte e l'idealismo trascendentale. Bologna: Il Mulino, 1992.

CESA, C. Der Begriff Trieb in den Frühschriften von J. G. Fichte (1792-1794). In: CESA, C.; HINSKE, N. (ed.). Kant und sein Jahrhundert. Gedenkschrift für G. Tonelli, Frankfurt a. Main: Klostermann, 1993. p. 165-185.

CESA, C. Sensibilité et conscience: remarques sur la théorie des Triebe chez Fichte. Revue Germanique Internationale, v. 18, p. 121-132, 2002.

CESA, C. Praktische Philosophie und Trieblehre bei Fichte. In: ZÖLLER, G. (ed.). Fichtes Praktische Philosophie. Eine Systematische Einführung. Hildesheim: Olms, 2007. p. 21-37.

D’ALFONSO, M. La genesi dello spazio semantico nella tarda filosofia di Fichte. Rivista di Storia della Filosofia, v. 4, p. 663-682, 2014.

DEDEURWAERDERE, T. Structure d'éveil et pouvoir d'inference pratique dans la phénoménologie génétique. In: GODDARD, J. C. (ed.). Fichte: la philosophie de la maturité (1804-1814). Paris: Vrin, 2008. p. 253-269.

DERRIDA, J. Interpretazioni in guerra. Kant, l'ebreo, il tedesco. Napoli: Cronopio, 2001.

DEVALQUE, A. La critique néokantienne de Kant et l'instauration d'une théorie conceptualiste de la perception. Dialogue, v. 49, p. 413-433, 2010.

DI GIOVANNI, G. Karl Leonhard Reinhold and the enlightenmen. Dordecht-HeidelbergLondon-New York: Springer, 2010.

FABBIANELLI, F. Antropologia trascendentale e visione morale del mondo. Fichte e il suo contesto; Milano: Guerini, 2000.

FERRAGUTO, F. L'osservazione fenomenologica dei fatti della coscienza in Fichte. Rivista di Storia della Filosofia, v. 69, n. 4, p. 619-639, 2014.

FERRAGUTO, F. A reflexão sobre a natureza e o problema da aplicação: entre realismo racional e filosofia transcendental (1799-1801). Dois Pontos, p. 27-43, 2015 a.

FERRAGUTO, F. Ser, saber, pensamento: a confrontação de Fichte com o realismo racional de Bardili e Reinhold. Aurora, p. 819-840, 2015 b. 
FICHTE, J. G. Gesamtausgabe der Bayerischen Akademie der Wissenschaften, hrsg. von R. Lauth, H. Jacob und H. Gliwitzky, Stuttgart-Bad Cannstatt: Frommann-Holzboog, 1962-2013; I, Obras; II, Obras Postumas; III, Correspondência; IV, Lições.

FICHTE, J. G. Fichtes sämtliche Werke. Berlin: De Gruyter, 1846.

FRANK, M. Unendliche Annäherung - Die Anfänge der philosophischen Frühromantik. Frankfurt: Suhrkamp, 1997.

GODDARD, J. C. Fichte est-il réactionnaire ou revolutionnaire? In: GODDARD, J. C.; RIVERA DE ROSALES, J. (ed.). Fichte et la politique. Monza: Polimetrica, 2008. p. 483-501.

HENRICH, D. Konstellationen. Stuttgart: Cotta, 1991.

HENRICH, D. Grundlegung aus dem Ich. Frankfurt am Main: Suhrkamp, 2004.

HENRICH, D. Konstellationsforschung zur klassischen deutschen Philosophie. Motiv - Ergebnis - Probleme - Perspektiven - Begriffsbildung. In: Konstellationsforschung. Frankfurt a. Main: Suhrkamp, 2005. p. 15-30.

IACOVACCI, A. Idealismo e nichilismo: la lettera di Jacobi a Fichte. Padova: CEDAM, 1992.

IVALDO, M. Libertà e ragione: l'etica di Fichte. Milano : Musia, 1992.

IVALDO, M. L'approccio pratico-etico alla storia nella filosofia trascendentale di Fichte. In: IVALDO, M.; MASULLO, A. (ed.). Filosofia trascendentale e destinazione etica. Indagini su Fichte. Napoli: Guerini, 1995. p. 199-224.

IVALDO, M. Politik, Geschichte und Religion in der Staatslehre von 1813. FichteStudien, v. 11, p. 209-227, 1997.

IVALDO, M. Fichte zu Jacobi in der ersten Transzendentalen Logik von 1812. FichteStudien, v. 14, p. 107-119, 1998.

IVALDO, M. Fichte: l'orizzonte comunitario dell'etica (le lezioni del 1812). Teoria, p. 37-54, 2006.

KÖHNKE, K. C. The rise of neo-kantianism: German philosophy between idealism and positivism. Tradução de R. Hollingdale. Cambridge: Cambridge University Press, 1991.

LASK, E. Fichtes Idealismus und die Geschichte, Tübingen: Möhr, 1903 (repr. Tübingen: Scheglmann, 2003).

LASK, E. Gesammelte Schriften, Tübingen: Mohr \& Siebek, 1923.

LAUTH, R. L'idée totale de la philosophie d'aprés Fichte. Archives de Philosophie, v. 28, n. 4, p. 567-604, 1965.

LIEBMANN, O. Kant e gli epigoni, Napoli: Guida, 1990.

LUKÁCS, G. Emil Lask. Nachruf. Kant-Studien, v. 22, p. 349-370, 1918. 
MAIMON, S. Gesammelte Werke. Hildesheim: Olms, 1965.

MARION, J.-L. Esquisse d'un concept phénoménologique du sacrifice. Archivio di Filosofia, v. 76, n. 1, p. 9-22, 2008.

MCDOWELL, J. Mind and world. Harvard: Harvard University Press, 1996.

ÖSTERREICH, P. L. Politische Philosophie oder Demagogie? Zur rethorischen Metakritik von Fichtes Reden an die deutsche Nation. Fichte-Studien, v. 2, p. 74-88, 1990.

PACI, E. Pensiero, esistenza, valore. Milano: Principato, 1940.

PICK, G. Die Übergegensätzlichkeit der Werte. Tübingen: Mohr, 1921.

RAMETTA, G. Lidea di filosofia nel tardo Fichte. Rivista di Storia della Filosofia, n. 3, p. 461-468, 2003.

RAMETTA, G. Fichte. Roma: Carocci, 2013.

RICKERT, H. Der Gegenstand der Erkenntnis. Freiburg: Wagner, 1892.

RICKERT, H. Fichtes Atheismusstreit und die Kantische Philosophie. Eine Säkularbetrachtung. Kant-Studien, v. 4, p. 137-166, 1990.

ROCKMORE, T. Fichte, Lask, and Lukács's hegelian marxism. Journal of the History of Philosophy, v. 30, n. 4, p. 557-577, 1992.

SCHULZE, G. E. Aenesidemus. Berlin: Reuther und Reichard, 1911.

SMITH, B.; MULLIGAN, K. Two idealisms. Lask and Husserl. Kant-Studien,v. 83, p. 448-466,1993.

SPINELLI, A.. Vita, teoria e valore nel pensiero di Emil Lask. Messina: Diss, 2010.

STEPUN, F. Wie war es möglich? Briefe eines russischen Offiziers. München: Hanser, 1929.

TUOZZOLO, C. Emil Lask e la logica della storia. Milano: Franco Angeli, 207.

WINDELBAND, W. Präludien. Tübingen: Mohr2, 1907.

WINDELBAND, W. Storia della filosofia moderna. T. III. Firenze: Vallecchi, 1925.

WINDELBAND, W. A history of philosophy (1901). s.l.: Nabu, 2010.

ZAHN, M. Fichte, Schelling und Hegels Auserinandersetzung mit dem "Logischen Realismus" Chritoph Gottfried Bardilis. Zeitschrift für Philosophische Forschung, v. 19, n. 2, p. 201-223; 464-471, 1965.

ZÖLLER, G. From critique to metacritique: Fichte's transformation of Kant's transcendental idealism. In: The Reception of Kant's Critical Philosophy: Fichte, Schelling, Hegel. Cambridge: Cambridge University Press, 2000a. p. 126-146. 
ZÖLLER, G. German realism. The self-limitation of idealist-thinking: Fichte, Schelling, Schopenhauer. In: The Cambridge Companion to German Idealism. Cambridge:

Cambridge University Press, 2000b. p. 200-218.

ZÖLLER, G. Leben und Wissen. Der Stand der Wissenschftslehre beim letzten Fichte. In: IVALDO, M.; MORETTO, G.; FUCHS, E. (ed.). Der transzendentalphilosophische Zugang zur Wirklichkeit. Stuttgart-Bad Cannstatt: Fromman-Holzboog, 2001. p. 307330.

ZÖLLER, G. "Nation comune": l'idée fichtéenne d'une histoire universelle de l'Europe au point de vue cosmopolitique. In: RIVERA DE ROSALES, J.; GODDARD, J. C. (ed.). Fichte et la politique. Monza: Polimetrica, 2008.

ZÖLLER, G. A segunda pessoa: a contribuição sistemática de Fichte. Cadernos do CRH, v. 25, p. 39-55, 2012.

Recebido: 23/08/2016

Aceito: 16/06/2017 